LWSA

PAPER - OPEN ACCESS

Structure and Function of Expressions of Peoples Trust (Superstitions) The villagers of Sigodang Village, Simalungun Regency

$\begin{array}{ll}\text { Author } & : \text { Asriaty R Purba et al. } \\ \text { DOI } & : 10.32734 / \text { lwsa.v3i4.1120 } \\ \text { Electronic ISSN } & : 2654-7066 \\ \text { Print ISSN } & : 2654-7058\end{array}$

Volume 3 Issue 4 - 2020 TALENTA Conference Series: Local Wisdom, Social, and Arts (LWSA)

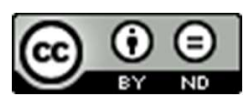

This work is licensed under a Creative Commons Attribution-NoDerivatives 4.0 International License.

Published under licence by TALENTA Publisher, Universitas Sumatera Utara

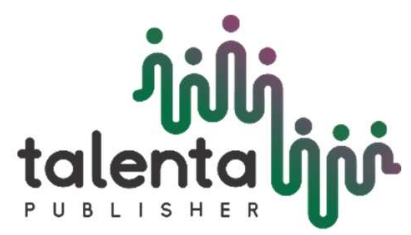




\title{
jibli

\section{Structure and Function of Expressions of People's Trust (Superstitions) The villagers of Sigodang Village, Simalungun Regency}

\author{
Asriaty R Purba, Herlina, Jamorlan Siahaan \\ Faculty of Cultural Sciences, University of Sumatera Utara, Jalan Dr. T. Mansur No. 9 Medan, 20222, Indonesia
}

asriatyr@gmail.com

\begin{abstract}
This research aims to describe the structure and function of expressions of people's trust in the village of Sigodang, Simalungun Regency. The expression of people's trust is one of type folklore as a verbal which consists of verbal and non-verbal elements. Poeple's trust in general contains the values that regulate the relationship between fellow humans, and humans with their natural and surrounding, to regulate and supervise the norms prevailing in society. The metho $\mathrm{d}$ of data collection that used in this research is a qualitative descriptive method, and used the folklore theory. The results of this research indicate that: 1 . The structure of people's trust expression in Sigodang Village consist of a. two structured expressions with a cause and effect pattern, and pattern of signs and effects., b. three structured expressions with a causal-conversion pattern, and causal-conversion pattern.; 2. The function of people's trust expressions is: a. thickener of religious emotions or trust., b. as an educational tool for children and teenager., c. as a collective dream projection system., d.as a means of coercion and supervisor so that the norms of society are always obeyed by collective members.
\end{abstract}

Keywords: structure; function; and people's trust; Simalungun.

\section{Introduction}

Basically, the Indonesian nation has a regional background. Each region has its own culture that make it different from other regions. Generally, culture can be defined as the overall knowledge, trust, and the values of norms that are shared by a group of people and disseminated orpassed down by verbal from a generation to the next generation.

One of the elements of culture is a language. Language is a characteristic of a region certain and also a habit that is inseparable from life, language is a characteristic of society, ethnicity, and customs. Language is used as a communication tools to interact in conveying ideas, and concepts. Language and culture has a close relationship. Therefore there is an opinion that says that language is very influenced by culture, everything in culture will reflected in language. This can be seen in the culture of the Simalungun people, where since ancient times

there have been quite a number of prohibited daily utterance or behaviors, because it is considered a taboo or pamali. Avoiding things what is considered as taboo is a part of the socio- cultural life of the Simalungun community. Where in general this habit is related to the principles of life. One of them is an expression of the people's trust that until now there are still people that believe in it even some still do that, but the truth is related about people's trust is often returned to the individual.

People's trust are also known as superstitions. People's trust is a part of folklore which contains of moral vaues that reflects the personality of the community of the owner and can also be used as a education tool for the community. An expression of popular trust as a cultural treasure needs to be preserved considering that expressions of popular trust in ancient times also function as a means of social control. However, nowadays many of the younger generations 
don't know nor do they care. This also happened with the disappearance of the older generation andalso because the influence of religion and the development of technological advances, especially in the younger generation urban life. Most of the older generation is more preoccupied with work routines. Likewise the children had more school activities outside the home, so it was time to gather at home has decreased. This condition also causes culture about people's trust as a wealth of verbal literature is rarely heard in the younger generation.

Therefore, in order not to become extinct, the culture of the people's trust of Simalungun community needs to be explored and documented and preserved so that it is not displaced by the rapid development of the times.

\section{Theory}

The theory used in this research is folklore theory. Dananjaya (1991:2) propose that folklore is the culture of a collective, which is spread and passed down from generation to generation, among any kind of collective, traditionally and different versions, both in verbal form and examples accompanied by gestures or reminders (mnemonic device). Furthermore, Yadnya (in Endaswara, 2013: 2) propose that folklore is part of culture that is traditional, unofficial, and national. This view implies that folklore is not only in ethnic character but also in national character and its transmission is not official. Folklore can be used as an educational tool or as a source of children's education, as a means of a controlling norms in society that must be obeyed.

According to Yan Harold Brunvand quoted by Dananjaya (1991: 21), folkor can divided into three groups, namely: verbal folklore, partially verbal folklore, and non-verbal folklore.

a. Verbal folklore which is purely verbal that consists of folk speech, traditional expressions, traditional questions, folk and poetry, and traditional chants.

b. Partially verbal folklore is a folklore whose form is a mixture of verbal and non-verbal elements. Such as folk trusts, folk games, folk parties, folk dances and others.

c. Non-verbal folklore consists of: the material sub-group, namely folk architecture, folk food, folk jewelry, traditional medicines, and the non-material sub-group, namely gestures.

\subsection{People's Trust}

The expression of people's trust (superstition) is partially verbal folklore, it means that people's trust consists of verbal statements plus gestures that are considered to have magical meanings. One form of people's trust that can be associated with the supernatural is the expression of prohibitions that must be obeyed by the community. Expressions of people's trust are passed down from generation to generation and are general in nature, the age of the speakers not limited, but in fact this expression of belief is only the elderly who know it.

People's trust for people with western education is considered simple and even stupid, because it is not based on logic, so scientifically it cannot be justified. The word of superstition is thought to have an insulting or degrading meaning.Therefore, modern folklore experts prefer to use as the term of people's trust (folk belief) rather than superstitious. Superstition means delusion.

People's trust is a belief and also a practice (habit) that is generally passed on through the media of speech, which is explained with conditions, consisting of signs or causes and those that will be estimated to exist consequence (result). For example, in the Simalungun language, if the voice of the Amang (sign) is heard, it will rain (consequently).

Dundes in Danandjaya (1991: 154-155) divides the structure of trust expressions into two types, first: expressions that are structured in two parts, namely cause and effect, and second, namely expressions that have a three-part structure, namely a sign, a change from one state to a others state (conversion), and the effect (result). This second structure is also subdivided according to the location of the conversion, there is a conversion located at the end and some located in the middle.

Furthermore, Danandjaya (1991) functions of expressions of people's trust are: a) as a thickening of religious emotions or trust, b) as an imaginary projection of a collective originating from the hallucinations of someone who 
is experiencing mental disorders, c) as a education tools of children or adolescents, d) as an acceptable explanation by a folk sense of natural phenomena that are difficult to understand so that it is very frightening, so that efforts can be taken to overcome them, e) as entertainment for people affected by the disaster.

\section{Result and Discussion}

\subsection{People's Trust Structure}

The people's trust structure consists of a two and a three structure. As forthe structure of people's trust (superstition) in the Simalungun community in the village of Sigodang as follows:

\subsubsection{Structured two consisting of cause and effect}

This people's trust structure (superstition) takes two forms. The first form describes the cause of something. The second form is the end result of an event about the activities that preceded it (effect). Here's an example of the people's trust (superstition) of the Simalungun community with a causal pattern:

\section{a. Ulang hundul ilobei ni labah holi payah roh rongkap}

It means: don't sit in front of the door, it's hard to find a mate later. This people's trust (superstition) has a pattern of cause and effect caused by human actions that are considered wrong. The first part, namely ulang hundul ilobei ni labah (don't sit in front of the door) is the cause of the next incident if it done. The second part is holi payah toh rongkap, (later it will be difficult to find a mate) is the result of if the previous action was done.

\section{b. Ulang sasou parsahapan ase ulang manggila pangian ni talun}

It Means: Do not speak carelessly so as not to get angry with the inhabitants of the area. The people's trust (superstitions) above are also causal. Ulang sasou parsahapan (don't speak carelessly) is the cause, then ase ulang manggila pangian ni talun (so as not to get angry with the inhabitants of the area) is the result.

\subsubsection{Double-structured consisting of signs of effect}

This people's trust structure (superstition) takes two forms. The first form is the presence of a sign. The second form is the result of the sign. Examples of people's trust (superstitions) with a pattern of consequences on the people's trust (superstitions) of the Simalungun community are as follows:

a. Anggo roh appul-appul hu jabu aima tanda ni lau roh tamu

It means: When a butterfly comes into the house, it indicates that there will be guests. People's trust (superstition) has a pattern of signs and consequences. The sentence which is a sign of people's trust (superstition) is anggo roh appul-appul hu jabu (if the butterflies come home). Whereas the result that arises from this sign is aima tandani lau roh tamu (that indicates the arrival of guests).

\section{b. Anggo kiok hu rumah, aima artini suruhan halak na lau mambahahen na masambor}

It means: If the snake comes into the house, that means a message from people who want to make a danger. People's trust (superstition) above is also a sign -and-effect pattern due to similarities in nature, namely drought. Anggo kiok hu rumah (if the snake comes to the house) is the cause, while the result is aima artini suruhan halak na lau mambahahen na masambor (it means that orders from people who want to make a danger). 


\subsubsection{A triple structure consisting of causal conversion}

This structure is preceded by the cause of an event (cause), followed by a change in an event (conversion) and followed by a change in the outcome of the event (effect). An example of a cause-conversion-effect pattern on the people's trust (superstitions) of the Simalungun community are as follows:

\section{a. Anggo okkakan, isondukma bah pake sonduk buluh baru minum ase mayup kokak na lokkot ai.}

It means: If the thorns of fish is sticky in the throat, scoop out the water using a spoon made of bamboo and drink them to wash away the sticky spines. The first form of anggo okkakan (if the spines of fish stick in the throat) is the cause of a subsequent event (cause). Then followed by the conversion form of isondukma, using sonduk reeds, then drink it (spoon the water using a spoon made of bamboo then drunk). This section changes the ending event from being supposed to be choking, to not being choked by thorns. Then it ends with the resulting form of ase mayup kokak na lokkot ai (to wash away the sticky spines) that is the result of the change in the situation.

\section{b. Anggo manuan durian atap pe duku isuan ma bani bokou ni bulan ase baggal-baggal buahni janah dokah matei}

It means: It means: If you plant durian or duku, plant it during the full moon so that the fruit is big and the tree will be has long lasting time. The people's trust (superstition) above is also a cause-conversion-effect pattern. Anggo manuan durian pe duku (if planting durian or duku) is the cause, the issue of ma bani bokou ni bulan (planted during the full moon) is a conversion, and finally the baggal-baggal of buahni janah dokah matei (so that the fruit is large and the tree will be has last long lasting time) is the result of conversion.

\subsubsection{A triple structure consisting of casual conversion}

This last form has a pattern that begins with the cause of an event, followed by the result of the change in the event (effect), then ends with a change in the event that occurs (conversion). In other words, we describe the results of the changes in the events that occur first, then the changes in the events will be presented. Examples of people's trust (superstition) which have a causal-conversion pattern of the people's trust (superstition) of the Simalungun community are as follows:

\section{a. Anggo lau hu harangan, ase ulang jumpah pakon kiok ampa lipan ikantungi ma siak si gerger}

It means: If you want to go to the forest, so you won't encounter snakes or centipedes, you have to pack the red chilies. People's trust above is the first from that anggo lau hu harangan (if you want to go the forest) is the cause of subsequent event. Then followed by the consequence of the change in events that will occur, namely a repeat meeting of pakon kiok ampa lipan (so you won't encounter snakes or centipedes). Then it ends with changes in the events that occur (conversion), namely ikantungi ma siak si gerger (red chilies bags).

b. Anggo iboan dakdanak hu rumah ni hasoman, tapi lang dong mambere atak aha pe hasoman ai, ase ulang ilukan ia, ikiskisma dinding jabuni hasoman ai, ibuat baru ibere ma bani niombah ai irik manghatahon "ulang ilukan ho da anggiku”

It means: If you bring the children to someone's house, but nobody gives anything to the person, so that the child doesn't want (wants something), then the walls of the person's house will be scrape. Then, it takes and then given to the child, while saying "please, don't want it, my son." This people's trust (superstition) also has a causal-conversion pattern. The form of anggo iboan dakdanak hu rumah ni hasoman, tapi lang dong mambere atak aha pe hasoman ai (if you bring children to someone's house, but nobody gives the person anything) is the cause. The re-form of his illusion (so that the child does not want (wants something)) is the result. Meanwhile, the form of ikiskisma dinding jabuni hasoman ai, ibuat baru ibere ma bani niombah ai irik manghatahon "ulang ilukan ho da anggiku" (then the wall of the person's house will be scrape, then takes and then given to the child, while saying "please, don't want it, my son") is a conversion. 


\subsection{A function of people's trust}

People's trust (superstition) is not just a delusion that has no function. People's trust (superstition) as a result of the thoughts of the Simalungun community that was made to have several functions. In order to be able to find out the functions contained in the people's trust (superstitions) that developed in the Simalungun community, then the authors used the people's trust functions (superstitions) put forward by Danandjaja and Bascom.

As for the function of people's trust (superstition) that mention is:

\subsubsection{As a Collection of Imaginary Projection Systems}

As a Collective Dream Projection System, it means that people's trust (superstition) is a means of reflecting the dreams of a person or group of people. In people's trust (superstition) which has this function, people who believe in it think that people's trust (superstition) will cause luck, safety, loss, accident or security if it done. This is an example of people's trust (superstition) which functions as a collective imaginary projection system that found in the Simalungun community:

\section{a. Ulang manggunting sisilon bai borngin holi pondok umurni namatoras ta}

It means: Do not cut your nails at night, the lifespan of our parents will be short. This people's trust (superstition) is part of the projection of people's dreams when cutting nails at night. Logically cutting nails at night has nothing to do with the death of parents. This people's trust (superstition) is only a projection of the feeling of fear when cutting nails at night it will makes our hands can be bleed, because in ancient times lighting did not use the lights like now. In other words, this people's trust (superstition) is a projection so that there is no wound when cutting the nails due to insufficient lighting at night.

\section{b. Anggo lau pajong-jonghon jabu,, labah lobei pakon labah pudi lang boi pintor, maningon margelok ase ulang mayup rajoki}

It means: It means: If you want to build a house, the in the front of the door and the of back the door cannot be parallel, you have to turn so you don't drift away. This people's trust (superstition) also functions as a collective imaginary system related to sustenance. The house is a place to store our belongings. Here is the symbolized of house as a place to store sustenance. In front of the door is the entrance to the house which is considered as the entry point for sustenance, while the back door is the opposite, is considered the release of sustenance. When it viewed from the position of the door, if the front of door and the rear door are parallel, the distance will be easier so that it is considered that the fortune that has been obtained (for example money) will be easily to spent. Meanwhile, if the front of the door and rear doors are made to turn, it is considered that the sustenance will be difficult to get out because they are trapped by the spaces that are in the search for a way out. In other words, it can be concluded that if in front of the door and the back door are made to turn, so it is considered that the incoming sustenance will be difficult to get out so that the sustenance is stored in the house.

\subsubsection{As a Thickener of Religious Emotions or Trust}

As a thickener of religious emotions or trust, it means people's trust (superstition) functions to increase human belief in the existence of God or supernatural beings and ancestral spirits around us who are invisible but it make an impact. This type of people's trust (superstition) believes in the existence of these creatures through natural phenomena that cannot be explained by human reason. It causes the humans that believe in people's trust (superstition) besides believing in the existence of these creatures, they also take an action so that these creatures do not interfere with human life. Examples of people's trust (superstition) which have a function as a thickener of religious emotions or trust in the Simalungun community are as follows: 


\section{a. Ulang martauri i harangan holi ibalosi homing}

Meaning: Don't shout while calling people in the forest and the genie / ghost will answer it. This people's trust (superstition) is a reinforcement of the trust that there are genie / ghosts in the forest. The form of holi ibalosi homing (later answered by the genie / ghost) proves that the Simalungun community are sure that there are genies / ghosts who inhabit the forest, so they are not allowed to scream while calling out while in the forest. This is because Simalungun community trust that shouting and calling in the forest will be answered by a genie / ghost, not a human, then they will be lead to go to a place that we do not know or to the supernatural.

\section{b. Anggo mardalan bai tanoman, irik manghatahon "tabi da pung” ase ulang isisei pangian ni talun}

If walking in the grave, say "excuse me, pung" so that the occupants of the grave won't disturb you. This people's trust (superstition) also have functions as a thickener for people's trust in the existence of ancestral spirits. The Simalungun community believe that every human being has a spirit. When they die, these spirits do not immediately disappear, but they still live on earth but are in another realm. The Simalungun community also believe that the grave is the residence of those who have died. So if you walk past the grave, you have to say excuse me.

\subsubsection{As an Educational Tool for Children or Adoescents}

Apart of the two previous functions, people's trust (superstition) is also made to educate the children or adolescents. With the people's trust (superstition), it will improve or direct the character, attitude, and behavior of the child or adolescent in a better direction. Usually this people's trust (superstition) describe the negative effects if it is violated. The following is an example of people's trust (superstition) which functions as an educational tool for children or adolescents in the Simalungun community:

\section{a. Ulang mangan bani dua sapah, holi dua amang-amang ampa inang-inangni}

It means: do not eat on two plates, later you will have two husbands or wives. This people's trust (superstition) was made to educate teenagers to be polite. Eating with two plates at the same time is an insolence in the Simalungun community because it is considered like never eating or afraid of not getting food. If this is done, it will embarrass the parents because it is considered that the parents do not teach the ethics when eating to their children. So the people's trust (superstition) serves to teach the children about ethics and being good at eating.

\section{b. Anggo i juma ulang pangan-pangan irik mardalan, ase ulang roh pangian ni harangan}

It means: If on the land, don't eat while walking so that the forest dwellers don't come (wild boar, monkeys, etc.)This people's trust (superstition) teaches the children to eat while sitting quietly in the fields. This is because if the child continues to do it, it is feared that the rest or crumbs of the child's food will fall on the ground so that can invite the animals from the forest that will destroy the fields. So actually it is not the children who eat while walking that invite the forest animals, but the food scraps that fallen when the child eat while walking which causes the forest animals to come.

\subsubsection{As a Means of Coercion and Supervision so that the Norms of Society are always Obeyed by Collective Members}

The last function is to act as a means of coercion and supervision so that the collective members' norms are always obeyed it. In social life, there are always rules or norms. This type of people's trust (superstition) is made so that the rules and norms that apply to the community are not violated. The following are people's trust (superstitions) which function as a means of coercing and monitoring norms in the Simalungun community: 


\section{a. Lang boi mangalo bani tulangni holi isuan galuh lang tubuh}

It means: You must not fight against your uncle (the mother's older brother). Bananas will not grow up then. Logically, there is no relationship between fighting Uncle and growing bananas. So that the Simalungun community always respect their uncle. Uncle (tulang) is the one of the most respected parties in the Simalungun community, therefore it must be respected. In other words, this people's trust (superstition) was made so that the Simalungun community always obey the norms of courtesy in customs and society.

\section{b. Anggo domma marpudung saud ulang pot be itandangi garama na legan ase holi ulang hona uhum padan}

It means: If you have been married, you should not want the other men to visit you so that later you will not be subject to the contract law. This people's trust (superstition) is aimed at

women who have been married to the norms of decency. When proposed, it means that a woman agrees to be loyal to the man who proposed to her. It was during this agreeme nt that the two parties demonstrated faith to be faithful by binding a covenant. Promises are sacred to the Simalungun community. Breaking a promise is believed to bring karma to those who break it. Meanwhile, itandangi (visited) in the Simalungun community means that a woman is visited by her house by one or more men who do not have a partner to introduce or approach so that the woman wants to be the male partner who visits her. So, if a woman who

has been proposed is willing to visit her house, then the woman does not respect the man who has proposed to her as well as breaking the promise he had made. So, because the woman who had been married to broke her promise, it is believed that the woman will get karma

\section{Conclusion}

Based on the results of the analysis conducted by the researchers on people's trust (superstitions) in Sigodang Village, Simalungun Regency, it can be concluded as follows: The structure of people's trust (superstition) in the Simalungun community is divided into two patterns, namely a cause-effect pattern and a sign-effect pattern; and three patterns, namely the causal-conversion-effect pattern and the causal-conversion pattern; and people's trust (superstition) in the Simalungun community functions as a collective imaginary projection system, thickening religious emotions or trusts, as an educational tool for children or adolescents, and as a coercive and supervisor so that the norms are always obeyed by collective members.

\section{References}

[1] Chaer, Abdul.1995. Pengantar Semantik Bahasa Indonesia. Jakarta : Rineka Cipta.

[2] ----.1991. Folklor Indonesia : Ilmu Gosip, Dongeng, dan lain-lain. Jakarta : Grafiti Press.

[3] Endraswara, Suwardi. 2009. Metodologi Penelitian Folklor : Konsep, Teori dan Aplikasi. Yogyakarta : Media Pressindo.

[4] ----2013. Pendidikan Karakter Dalam Folklor : Konsep, Bentuk dan Model. Yogyakarta : Pustaka Rumah Suluh.

[5] Kuntowijoyo. 2006. Budaya dan Masyarakat. Yogyakarta. Tiara Wacana Yogya.

[6] Mahsun. 2012. Metode Penelitian Bahasa: Tahapan Strategi, Metode, dan Tekniknya. Jakarta: Rajawali Press.

[7] Moleong. J Lexy. 2010. Metodologi Penelitian Kualitatif. Bandung : Pt. Remaja Rosdakarya.

[8] Muslim, Bukhori. 2001. Analisis Bentuk, Makna dan Fungsi Takhyul Masyarakat Peringge Jurang Kabupaten Lombok Timur dan Relevansinya Terhadap Pendidikan di SMAN 1 Montong Gading Mataram : FKIP Universitas Mataram..

[9] Oktavianus. 2006. Nilai Budaya dalam Ungkapan Minangkabau : Sebuah Kajian dari Perpektif Antropologi Linguistik, dalam Journal Linguistik Indonesia. Tahun ke 24, Nomor 1 Februari 2006.

[10] Parera, JD. 1990. Teori Semantik. Jakarta : Erlangga.

[11] Saragih, J.Edison. 1989. Kamus Simalungun-Indonesia. Pematang Siantar: Sekawan.

[12] Sutarman. 2013. Tabu Bahasa dan Eufemisme. Surakarta : Yuma Pressindo. 